\title{
AN ANALYSIS OF TRANSITIVITY IN READING TEXT FOR SECOND GRADE STUDENTS' OF SENIOR HIGH SCHOOL
}

\author{
Annisa Nurhadi Maya; Eliza; Loli Safitri \\ Islamic State Institute (IAIN) of Bukittinggi \\ annnmaya22@gmail.com; lizachio89@yahoo.co.id; safitriloli28@gmail.com
}

\begin{abstract}
This research concerned transitivity in reading text for senior high school. The purposes of this research were to describe and to find out the dominant process types of transitivity occurred in the reading text. This research was descriptive qualitative. The data was obtained from reading text in English textbook entitled Pathway to English. The result of the research were six types of process that occurred in the textbook. There were material process $(38 \%)$, relational process $(30 \%)$, verbal process $(20 \%)$, mental process (19\%), behavioural process $(4 \%)$, and existential process $(2 \%)$. The dominant types of transitivity were material process. It means that reading passage in English textbook entitled Pathway to English contained action and physically. Furthermore, the benefit that can be gained from analyzing the transitivity in the text could stimulate the reading skills to comprehend the idea and information in a text that could be applied in spoken and written texts.
\end{abstract}

Keywords : Experiential meaning, Transitivity, Reading text, English textbook

\section{INTRODUCTION}

Implementation of the Curriculum 2013 in teaching English needed to consider an English textbook. A textbook was a book that contained several learning materials to support the learning and teaching process in the classroom. According to Masnur (2016), textbook was the book contains the material about specific subject of study that was arranged systematically and have been selected based on specific objectives, learning orientation and students development. It was used as learning tool in learning activities in school. Then, Klemencic and Vogrincic (2014) said that textbooks were core of learning materials or documents within the field of education both in printed but also in electronic form. It means that textbook was a media as learning tools which consisted of material that relevant topic or content to supporting the teaching and learning process in the classroom.

There were a lot of material provided in the textbook, for example, the text which usually presented in the form of reading section activity. Reading was the process of deciphering the contents of the text where the students needed their knowledge to get information from the text. Irwandi (2017) said that reading skills was the comprehensive expression of vocabulary, language structure, culture and reading speed. It is the interaction between the reader and the text. Reading skills enabled the students to get information from written text to comprehend the text. By reading text, students could gain the knowledge and information from all over the world without must around it. The students could grasp the meaning in the text and the students could analyze the social function, generic structure and language features of the text.

The branch of linguistics which discussed language meaning was called semantic. Meaning was the main element in written communication between reader and writer. Functional grammar was one of the studies of language meaning. Marbun and Lidia (2016) said that functional grammar was a study of sense and meaning in the context of grammar. It consisted of three main kinds of meaning. They were ideational, interpersonal and textual meaning. These three generalized meanings were termed "metafunction". Ideational meaning consisted of logical meaning and experiential meaning. Emilia (2014) said that the logical meaning focused on the relationship between ideas and the meaning between clause 
complex whereas the experiential meaning focused on content or ideas. According to Geoff (2014), experiential meaning was a way to use language to talk about the world. Experiential meaning focuses on the language in the clause level concerning the notion of the clause as representation. Clause as representation means that one function of the clause was a representation of the experience of both external and internal reality. Experiential meaning was realized by transitivity.

Transitivity was a grammatical system that deals with various types of processes and relate to content or ideas expressed in the clause. It explained the participants, processes, and circumstances. Marbun and Lidia (2015) said that transitivity was an important semantic concept in the analysis of the representation of reality. Transitivity was realized on activity, process, and situation. The process was central in transitivity. It was realized by verbs that carried the meaning. The transitivity system construed the world of experience into a manageable set of Process Types. Process types of language was classified into the various process. According to Emilia (2014), the transitivity system construct the world of experience into a manageable set of process types and there are different types of process which are: material, mental, verbal, relational, behavioral and existential.

In teaching grammar, grammar was taught in the classroom only focused on teaching traditional grammar, so it gave the perception that English was a set of grammatical rule. However, according to Zhiwen (2013), for a communicative purpose, the students needed to know how to use language in different situations. The students must be familiar with the school-based text. By analyzing the text, functional grammar could offer the students a way of seeing how meaning and form in the different options in the grammatical system and knowing how language was construed in school.

Based on the explanation above, the text was used to express a purpose in the context of situation and culture. By analyzing the transitivity in the text, it would fasilitate the teacher in teaching grammar and meaning in the text which aimed to communicate. It could help the teacher to build grammar in text analysis which was useful in spoken and written text. Functional grammar helped the teacher to increasing creativity in process teaching in the classroom. In addition, functional grammar also could help the students to think critically of a phenomenon. For example, the students were taught to analyze a reading text. From the text analysis, the students could train to analyze the relationship, meaning, content and purpose of the text.

In this research, the researcher analyzed the text to find out the process types of transitivity contained in the text. The text to be analyzed by the researcher was the English text of the textbook related to reading passage in reading section activity. In supporting the research, there were several relevant studies conducted by some researchers. The first, journal by Fathur Rizqi Arifiani (2017), with the title was Experiential Function in Reading Passage of English Textbook Your Practice English Competence grade $8^{\text {th }}$ for Junior High School. In their journal aimed to investigate the process type of experiential function in the text, the most dominant and described the implication of the most dominat process type for teaching English especially in reading passage of English textbook for $8^{\text {th }}$ grade Junior High School. Second was the study done by Ambar Jati (2016), "Functional Analysis of Narrative Texts in Elementary School Textbook "Fly With English". In their research aimed to analyze of narrative text in Elementary School textbook "Fly With English" based on lexicogrammar in the framework of Systemic Functional Linguistic. Finally, the researcher was interested in research by the title "An Analysis on Transitivity in the Reading Text for Second Grade Students' of Senior High School".

\section{METHOD}

The design of this research was descriptive qualitative research. Sugiyono (2014) said that qualitative research as the research method naturalistic because the researcher doing in 
natural setting as the direct resource of data and the researcher was the key instrument. This research also concerned analyzing the content of the text in the textbook. According to Ary (2010), content analysis was a research method that was applied to written material to identify the specific characteristics of the material. Material analysis could be in the form of textbooks, newspapers, web pages, speeches, or several other types of documents. After that, the data of this research was obtained from materials reading text in the English textbook entitled Pathway to English. The researcher collected ten text in the textbook in reading section activity. The source of the data was taken from English textbook for second grade students entitled Pathway to English from Erlangga publisher in 2017. The instrument of data gathering was called a documentation checklist. According to Arikunto (2002), the documentation checklist was a list of variables that collected the data. Then, the researcher gave a sign or tally on each indicator of the research variable. The researcher created the documentation checklist adapted from the indicator in the transitivity theory of Halliday and Emi Emilia in the form of a table. Then, the researcher gave a sign or tally on each indicator of the researcher variable. Furthermore, to verify the data, the researcher asked two raters to analyze the data by using the transitivity theory. Then, the researcher compared the result of the analysis of two raters and the researcher. Then, the process of the data analysis suggested by Gay (2012) as follows reading or memoing, describing, and classifying. The last, to find out the dominant process types of transitivity used in reading text, the researcher calculated the percentage to show the result of transitivity with formula :

$$
P=\frac{\mathrm{f}}{\mathrm{n}} \mathrm{x} 100 \%
$$

Note :

$\mathrm{P}:$ Percentage of the process type

$f$ : Frequency

$\mathrm{n}$ : The sum of the frequency

\section{FINDINGS AND DISCUSSION}

\section{Findings}

The researcher collected the data to answer the research questions "What are the process type of transitivity used in the text of textbook for second grade of senior high school?" and "What is the dominant process type of transitivity in the text of textbook for second grade of senior high school?" The researcher used the documentation checklist as the instrument. The data were taken from the textbook specifically in the text of reading section activity.

All the texts were classified into the report text, narrative text, and hortatory exposition text. The process types of transitivity would be analyzed was based on a clause in the text. The clause put on the table of data analysis of process types. The process types were classified into material process, mental process, relational process, behavioural process, verbal process, and existential process.

The researcher compared the result of analysis the data from two raters and the researcher. Then, the researcher found all six types of process of transitivity in the textbook. They were material process, mental process, relational process, behavioural process, verbal process, and existential process. The result of process types of transitivity was shown in the table below.

Table 1. The Result of Percentage of Process Types of Transitivity

\begin{tabular}{|l|l|l|l|l|l|}
\hline No & $\begin{array}{c}\text { Process Types of } \\
\text { Transitivity }\end{array}$ & Researcher & Rater I & Rater II & Percentage \\
\hline 1 & Material Process & $148(50 \%)$ & $144(48 \%)$ & $45(15 \%)$ & $38 \%$ \\
\hline
\end{tabular}




\begin{tabular}{|l|l|c|c|c|c|}
\hline 2 & Mental Process & $55(19 \%)$ & $67(23 \%)$ & $47(16 \%)$ & $19 \%$ \\
\hline 3 & Verbal Process & $27(9 \%)$ & $29(10 \%)$ & $5(2 \%)$ & $20 \%$ \\
\hline 4 & Behavioural Process & $6(2 \%)$ & $1(0 \%)$ & $33(11 \%)$ & $4 \%$ \\
\hline 5 & Relational Process & $58(20 \%)$ & $50(17 \%)$ & $160(54 \%)$ & $30 \%$ \\
\hline 6 & Existential Process & $3(1 \%)$ & $6(2 \%)$ & $7(2 \%)$ & $2 \%$ \\
\hline
\end{tabular}

From the table was known that all the processes types of transitivity appeared in the textbook. They were material process, mental process, verbal process, behavioral process, relational process and existential process. Then, the dominant process was material process which appeared in the textbook.

Based on research result, the researcher found six process types that occurred in the reading text. The first was material process. Material process was the process of doing and happening. Semantically, the material process indicates activities or events. This process referred to the physical experience of human beings. Below were the example clauses of material process which appeared in the text.

- They eat on average 116 coconuts each year

- She took an arrow

Second was relational process. The relational process construed being and relating among entities through attribution and identification. Relational process was divided into attributing relational and identifying relational. In the attributing relational process was the process which assigned a quality whereas identifying relational process was that something has an identify assigned to it. Below were the example clauses of relational process which appeared in the text.

- Home remedies are simple medication ( $\operatorname{Pr}:$ Relational - Attribute)

- That students are the right track (Pr : Relational - Identional)

Third was verbal process. The verbal process was the process of saying. This process showed activities related to information. It included that of saying and asking. Below were the example clauses of verbal process which occurred in the text.

\section{- Because Alan had told his private life}

The next was the mental process which was process of sensing. Mental process refered to verb indicating cognition, affection, and perception. Cognition referred to "thinking", affection refered to "feeling", and perception. Semantically, mental process involved sense which was inside the human. Below were the example clauses of mental process which appeared in the text.

- but I think (Pr: Mental-Cognition)

- that Hughie felt sorry for him (Pr : Mental-Affection)

- She caught sight suddenly of a woman (Pr:Mental-Perception)

The next was behavioural process which was the process of physiological and psychological behavior. Below were the example clauses of behavioural process which occurred in the text.

\section{- Alan laughing loudly}

The last was existential process which was the process of existence. This process 
represented that something exists or happens. According to Farzaneh (2011), the existential process was the processes of existing with a there and to be with no representational function. The existential process was recognizable because it was signaled by "there". Below were the example clauses of existential process which occurred in the text.

- There was no crown prince

- There is an argument

\section{Discussion}

Transitivity was a system of grammatical choice associated with content or ideas expressed in clause including how people are express the meaning of the experience. According to Halliday in Emilia (2014), the transitivity system construed the world experience into a manageable set of process types and it is divided into six types of process in English namely material process, mental process, verbal process, relational process, behavioural process, and existential process.

The researcher had analyzed the text in an English textbook for second grade of senior high school entitled "Pathway to English". The researcher collected ten texts in the textbook in the reading section activity. The type of text contained in the textbook was the type of report text, narrative text, and hortatory exposition text. Based on the analysis the text, the researcher found that all of the six process typess of transitivity occurred in the text. The most dominant type of process transitivity in a textbook was material process. It was suitable with the theory stated Ambar Jati (2016). In that journal was mentioned which all of the six process types of transitivity occurred in the textbook and the most dominant process types in that textbook was material process.

Furthermore, the suitability of the curriculum with the learning material was very important for the success of student learning. The curriculum 2013 was a curriculum that built students' character values. In the textbook, the author has followed the requirements in the curriculum of 2013. All types of text that had been determined in the syllabus were developed by the author in the textbook. Based on the syllabus, functional text that must be taught by the teacher in second grade senior high school included narrative text and hortatory exposition text. This type of text was already in the textbook and was followed by the syllabus.

Based on the research result, this research was expected to provide benefits in the analysis of reading text especially in the analysis of reading material. There were the benefit that could be gained in the analysis transitivity in the text. It could stimulate the reading skill to comprehend the idea and information in a text. Then, the content of the text gave the knowledge of reading and writing skills that can be applied in spoken and written text. Futhermore, The teacher could know the aspect of transitivity which contained in the reading textbook. Then, the teacher was also expected to teach functional grammar to improve students grammar which could be applied in writing or reading text.

\section{CONCLUSION AND SUGGESTION}

Based on finding of the research about the analysis transitivity in the text, it can be concluded that the researcher found that six processes types appeared in the text of textbook. The six types were material process, relational process, verbal process, mental process, behavioural process, and the last was existential process by the percentage sequentially were $38 \%, 30 \%, 20 \%, 19 \%, 4 \%$ and the las $2 \%$. Then, the dominant processes types of transitivity occurred in the text of textbook was material process which appeared as much $38 \%$ of result analysis of the text.

In addition, based on the result, researcher gave suggestion to the English teacher who could be teach functional grammar when the teacher teaching text and designed interesting material, so the students motivated to understand a text. Furthermore, the analysis 
transitivity gave benefit for the teacher to comprehend the transitivity in the text was facilitate the teacher in teaching grammar and meaning in the text which aimed to communicate. It could help the teacher to build grammar in the text analysis which was useful in spoken and written text.

\section{REFERENCES}

Arifiani, F. R. (2017). Experiential function in reading passage of english textbook your practice english competence grade 8th for junior high school. International Journal of Linguistics, 9 (3), 102. Retrieved from https://doi.org/10.5296/ijl.v9i3.11210

Arikunto, S. (2002). Prosedur penelitian suatu pendekatan praktek edisi revisi V. Jakarta: Pustaka Jaya.

Ary, D. (2010). Introduction to research in education ( $8^{\text {th }}$ ed). Belmont, CA: Wadsworth.

Emilia, E. (2014). Introducing functional grammar. Jakarta: Pustaka Jaya.

Feng, Z. (2013). Functional grammar and its implications for english teaching and learning. English Language Teaching, 6 (10). Retrieved from https://doi.org/10.5539/elt.v6n10p86

Haratyan, F. (2011). Halliday's SFL and social meaning. 17. Retrieved from http://www.ipedr.com/vol17/49-CHHSS\%202011-H10074.pdf

Irwandi, I. (2017). Integrating intercultural communication competence in english literature teaching: the aplication of reading novel, 2. Retrieved from http://ejournal.unp.ac.id/index.php/selt/article/view/8011

Jati, A. (2016). Functional analysis of narrative texts in elementary school textbook "fly with English". Retrieved from http://eprints.ums.ac.id/48256/34/Article\%20publikasi.Jati.pdf

Klemencic, E., \& Vogincic, M. C. (2014). Analysis of text in the field of education : a regulation on textbook approval and history of textbook. SAGE Open. Retrieved from http://doi.org/10.1177/2158244014552430

Marbun, L. A. Y. (2017). Process types of Transitivity in the national geographic's. Retrieved from https://www.semanticscholar.org/paper/Process-Types-of-TransitivitySystem-in-the-Marbun-Yanti/8604b432dca3feafaf8754ed107c37333768c1d1

Muslich, M. (2016). Dasar-dasar pemahaman, penulisan, dan pemakaian buku teks. Yogyakarta: Ar-Ruzz Media.

Sugiyono. (2018). Metode penelitian pendidikan: (pendekatan kuantitatif, kualitatif dan $R \& D)$. Bandung: Alfabeta.

Thompson, G. (2014). Introducing functional grammar. London: Routledge. 